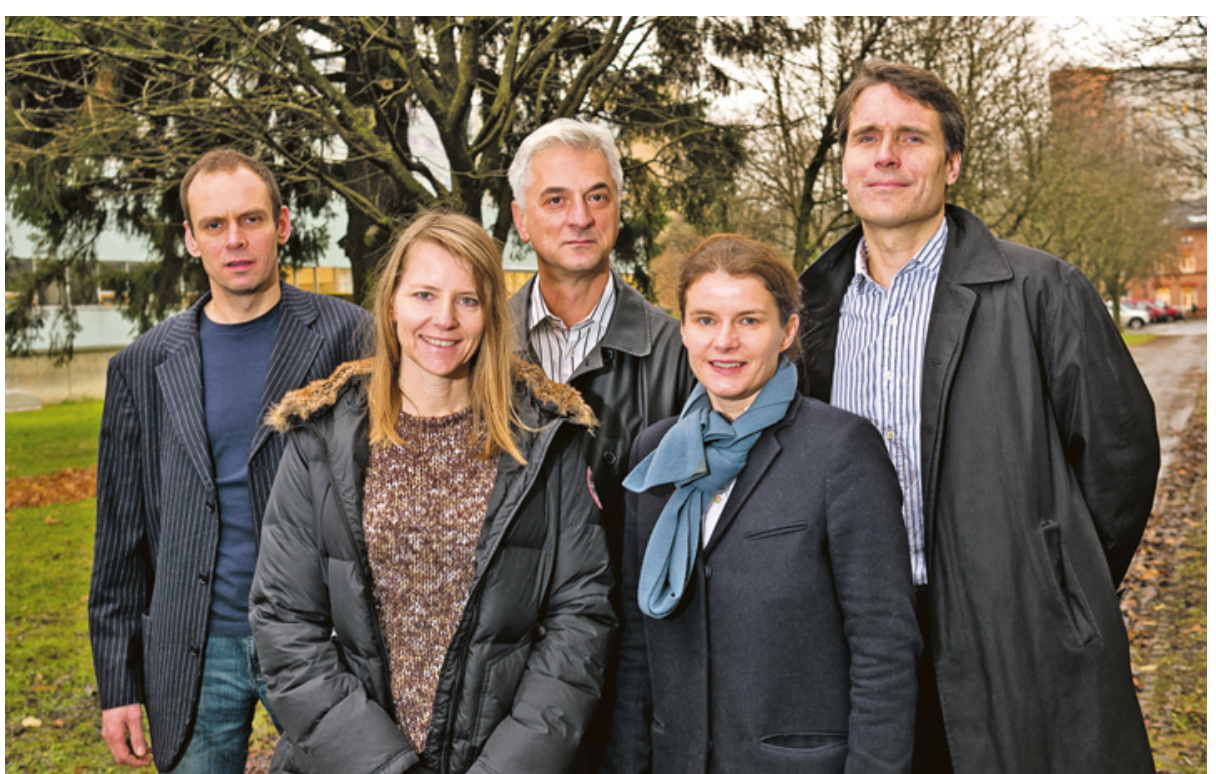

Fra venstre Thor Ueland, Annika Michelsen, Srdjan Djurovic, Ingrid Dieset og Ole A. Andreassen.

Foto Øystein H. Horgmo, Universitetet i Oslo

\title{
Inflammasjonsmarkører ved bipolar lidelse
}

\author{
Norske forskere har påvist økt ekspresjon av et immunrelatert gen \\ hos pasienter med bipolar lidelse.
}

Schizofreni og bipolar lidelse er komplekse sykdommer med opp mot $80 \%$ arvelighet. Flere nye studier har vist økt sykdomsrisiko ved visse genvarianter innenfor immunkomplekset på kromosom 6, som inneholder mange immunrelaterte gener, deriblant NOTCH4 $(1,2)$. Proteinet NOTCH4 er involvert i T-cellemediert immunrespons, inflammasjon i vaskulært endotel og i makrofagaktivering. I tillegg har det en regulerende funksjon i utviklingen av nerveceller i sentralnervesystemet.

Ekspresjon av NOTCH4-genet ble undersøkt hos 479 pasienter med schizofreni og bipolar lidelse og sammenliknet med tilsvarende hos 211 friske kontrollpersoner. I tillegg ble 20 enkeltnukleotidpolymorfismer i og rundt NOTCH4-regionen genotypet for å identifisere såkalte uttrykte kvantitative trekk-loci (eQTL).

Det var en statistisk høysignifikant høyere ekspresjon av NOTCH4 hos pasienter med bipolar lidelse sammenliknet med pasienter med schizofreni og med friske kontrollpersoner. Tre områder i genomet var sterkt assosiert med høyt nivå av NOTCH4-mRNA i blod.

- Resultatene er oppsiktsvekkende og tyder på at inflammasjon og spesielt NOTCH4-genet spiller en rolle i patogenesen ved bipolar lidelse, sier Ingrid Dieset, studiens førsteforfatter. At det var en spesifikk økning av NOTCH4 ved bipolar lidelse kan ha betydning med tanke på biomarkører av sykdommen, og også som en mulig ny

Ordforklaringer

NOTCH4: et transmembrant reseptorprotein som er involvert i kommunikasjonen mellom celler.

eQTL: (expressed quantitative trait loci) er områder innen genomet som regulerer ekspresjonsnivået av mRNA.

Genekspresjon: prosessen der informasjonen fra genene anvendes i syntesen av et ferdig genprodukt

behandlingstilnærming, da NOTCH-antagonister er under utprøving ved andre sykdommer, men det gjenstår mye forskning før dette kan prøves ut ved bipolar lidelse, sier Dieset.

\section{Forskergruppen}

Prosjektet utgår fra KG Jebsen Senter for Psykoseforskning ved Universitetet i Oslo, Oslo universitetssykehus og Universitetet i Bergen, og er basert på et samarbeid med Institutt for indremedisinsk forskning, Universitetet i Oslo, Seksjon for klinisk immunologi og infeksjonssykdommer ved Oslo universitetssykehus samt Den nasjonale satsingen på alvorlige psykiske lidelser, hvor en rekke psykiatriske avdelinger fra hele lander deltar. Studien inngår som en del av en større satsing der målet er å identifisere inflammatoriske virkningsmekanismer ved psykosesykdommer $\mathrm{i}$ håp om å identifisere nye angrepspunkter for medikamentell behandling.

\section{Erlend Hem}

erlend.hem@medisin.uio.no

Tidsskriftet

\section{Litteratur}

1. Stefansson H, Ophoff RA, Steinberg $\mathrm{S}$ et al. Common variants conferring risk of schizophrenia. Nature 2009; 460: 744-7.

2. Dieset I, Djurovic S, Tesli M et al. Up-regulation of NOTCH4 gene expression in bipolar disorder. Am J Psychiatry 2012; e-publisert 1.12.2012.

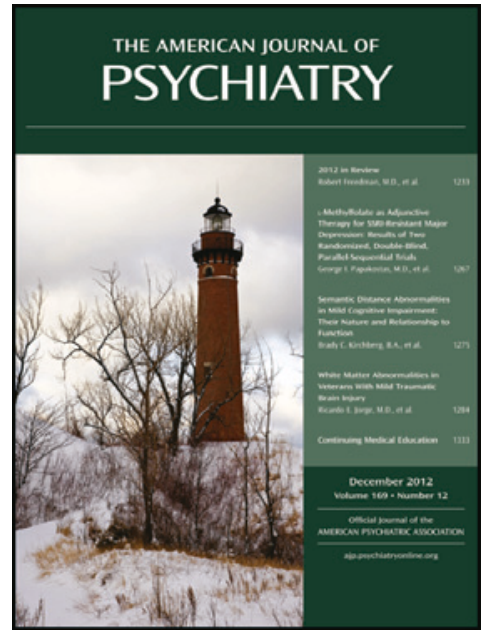

Artikkelen er publisert i desemberutgaven 2012 av American Journal of Psychiatry (http://ajp.psychiatryonline.org), som er et av de høyest rangerte tidsskriftene innen psykiatri 